\title{
KEEFEKTIFAN PENERAPAN MODEL PEMBELAJARAN BERBASIS PROYEK TERHADAP KEMAMPUAN PEMECAHAN MASALAH PESERTA DIDIK PADA MATERI BIOTEKNOLOGI
}

\section{THE EFFECT OF APPLICATION OF BASED PROJECTS LEARNING MODEL ON THE ABILITY OF TRAFFIC SOLVING PARTICIPANTS IN BIOTECHNOLOGY MATERIALS}

\author{
Nurul Arifah Sofyan ${ }^{1}$, Hamka L ${ }^{2}$, Andi Rahmat Saleh ${ }^{3}$ \\ Jurusan Biologi, FMIPA \\ Universitas Negeri Makassar \\ Nurularifahsofyan@gmail.com ${ }^{1}$
}

\begin{abstract}
This pre-experimental research aimed to determine effectiveness of project-based learning model implementation towards problem solving ability of students on biothecnology subject matter. This research hypotesized that implementation of project-based learning model is effective towards problem solving ability of students on biotechnology subject matter. Average score of problem solving ability obtained at pretest was 29.46, while at posttest was 69.25. Effectiveness of projectbased learning model implementation was assessed with inferential statistical analysis using SPSS 18 and the results was significant. (2-tailed) $0.000<\alpha=0.05$, which means that $H_{0}$ rejected and $H_{1}$ accepted, thus indicating that the hypothesis accepted. As for assessing effectiveness level, an $N$-gain test was used, which showed that the level of effectiveness of project-based learning model implementation was 37 (92.5\%) of total students obtained N-gain in the middle and / or high range category. Based on this results, it can be concluded that the project-based learning model implementation is effective towards the problem solving ability of students on Biotechnology subject matter.
\end{abstract}

Keywords: Biotechnology, Problem solving ability, Project-based learning

\begin{abstract}
Abstrak
Penelitian pra-eksperimen ini bertujuan untuk mengetahui keefektifan penerapan model pembelajaran berbasis proyek terhadap kemampuan pemecahan masalah peserta didik pada materi bioteknologi. Hipotesis penelitian ini adalah penerapan model pembelajaran berbasis proyek efektif terhadap kemampuan pemecahan masalah peserta didik pada materi bioteknologi. Nilai kemampuan pemecahan masalah peserta didik diperoleh rata-rata pretest 29.46 dan rata-rata posttest 69.25 . Keefektifan penerapan model pembelajaran berbasis proyek diukur melalui analisis statistik inferensial menggunakan SPSS 18 dan diperoleh hasil sig. (2-tailed) $0,000<\alpha=0,05$ yang berarti $\mathrm{H}_{0}$ ditolak dan $\mathrm{H}_{1}$ diterima, sehingga menunjukkan bahwa hipotesis diterima. Adapun untuk mengukur tingkat keefektifannya, digunakan uji $N$-gain, yang menyatakan bahwa tingkat keefektifan dari penerapan model pembelajaran berbasis proyek adalah sebanyak 37 orang $(92.5 \%)$ dari peserta didik memiliki $N$-gain pada kategori sedang dan/atau tinggi. Berdasarkan hasil penelitian dapat disimpulkan bahwa penerapan model pembelajaran berbasis proyek efektif terhadap kemampuan pemecahan masalah peserta didik pada materi Bioteknologi.
\end{abstract}

Kata kunci: Bioteknologi, Kemampuan pemecahan masalah, Model pembelajaran berbasis proyek

\section{PENDAHULUAN}

Abad pengetahuan saat ini, menginginkan paradigma belajar yang berorientasi pada proyek, masalah, penyelidikan, penemuan dan penciptaan. Tuntutan dunia pendidikan juga menuntut peningkatan kemampuan akademik. Selain itu, peserta didik juga dituntut untuk dapat 
meningkatkan kemampuan personalnya (softskill) sebagai persiapan untuk memasuki jenjang pendidikan yang lebih tinggi serta dunia kerja yang memerlukan orang yang dapat mengambil inisiatif, berfikir kritis, kreatif, dan pemecahan masalah. Guru dituntut untuk mengembangkan potensi diri yang dimiliki peserta didik sejak dini dengan melakukan berbagai variasi dalam proses pembelajaran.

Hasil survei The Conference Board, Corporate Voices for Working Families, Partnership for $21^{\text {st }}$ Century Skills, dan The Society of Human Resources Management yang dirilis pada tanggal 2 Oktober 2006, kecakapan paling penting untuk bisa sukses bekerja ketika lulus SMA salah satunya adalah berpikir kritis dan kemampuan memecahkan masalah (58\%). Adapun kelemahan yang dimiliki siswa lulusan SMA ketika mereka diterima kerja salah satunya adalah berpikir kritis dan memecahkan masalah $(70 \%)$. Dari hasil survei tersebut menunjukkan bahwa kemampuan pemecahan masalah, berpikir kritis, kolaborasi, dan komunikasi menjadi hal yang sangat penting yang harus dimiliki oleh siswa agar mampu bersaing dengan siswa lain [5].

Pada beberapa sekolah, penilaian formal pemecahan masalah dianggap hanya dapat digunakan di kelas matematika saja. Hal ini tentunya mengabaikan kenyataan bahwa kemampuan pemecahan masalah mencakup di semua bidang kehidupan. Masalah timbul di masyarakat secara keseluruhan hingga di laboratorium sains sekalipun [7]. Kemampuan pemecahan masalah tidak hanya digunakan dalam penyelesaian permasalahan sains dalam bentuk matematis, namun bagaimana memecahkan masalah terhadap berbagai fenomena yang terjadi di lingkungan sekitar, misalnya yang berkaitan dengan pemanfaatan potensi sumber daya alam lokal melalui bioteknologi.

Berdasarkan data yang dilansir dari Badan Standar Nasional Pendidikan, dikemukakan bahwa mutu dan kualitas pendidikan nasional mengalami ketertinggalan jika dibandingkan dengan negara tetangga lainnya, terutama jika dilihat dari indikator HDI (Human Development Index) dan berbagai indikator kinerja lainnya [4]. Oleh karena itu, dibutuhkan suatu model atau metode pembelajaran yang tidak hanya membuat peserta didik aktif, melainkan sesuai pula dengan pembelajaran abad 21, salah satunya yaitu model pembelajaran berbasis proyek.

Beberapa sekolah di berbagai negara telah menerapkan pembelajaran berbasis proyek dalam proses pembelajarannya diantaranya adalah Ninestiles School di Birminghm, Inggris, Homewood School di Kent, Inggris, Crow Island Elementary School di Winnetka, Illinois, dan New Technology High School di Amerika Serikat yang secara khusus dibuat sebagai fitur model dari sekolah yang $100 \%$ menerapkan pembelajaran berbasis proyek [6]. Di sisi lain, model pembelajaran berbasis proyek di Indonesia khususnya di Sulawesi Selatan baru mulai direkomendasikan untuk digunakan di sekolah oleh tim pengembangan kurikulum 2013. Selain itu, pada pelatihan kurikulum 2013 yang diikuti oleh guru-guru, sebagian besar guru masih kesulitan dalam menerapkan model pembelajaran berbasis proyek [19].

Melihat situasi tersebut, maka peneliti tertarik untuk mengkaji keefektifan penerapan model pembelajaran berbasis proyek terhadap kemampuan pemecahan masalah peserta didik kelas IX pada materi bioteknologi sebagai upaya memberikan informasi yang lebih akurat terkait keefektifan implementasi model pembelajaran berbasis proyek di sekolah.

Menurut kamus besar Bahasa Indonesia keefektifan berarti keadaan berpengaruh, hal yang berkesan, dan keberhasilan suatu usaha atau tindakan. Adapun dalam pembelajaran, keefektifan diartikan sebagai hasil guna yang diperoleh setelah pelaksanaan proses belajar mengajar [17]. Keefektifan pembelajaran sangat dipengaruhi oleh banyak hal. Beberapa faktor yang memengaruhi keefektifan belajar siswa terdiri atas dua yaitu: (1) faktor internal siswa berupa aspek fisiologis dan aspek psikologis (2) pendekatan belajar [18].

Model pembelajaran berbasis proyek merupakan sebuah model pembelajaran yang berfokus pada prinsip-prinsip utama dari suatu disiplin, melibatkan peserta didik dalam kegiatan pemecahan masalah dan tugas-tugas 
bermakna lainnya, memberi peluang peserta didik bekerja secara otonom mengonstruksi belajar mereka sendiri, dan puncaknya menghasilkan produk karya yang bernilai dan realistik [11]. Beberapa keuntungan dari pembelajaran berbasis proyek, antara lain: (a) meningkatkan motivasi belajar siswa, (b) meningkatkan kemampuan pemecahan masalah, membuat siswa lebih aktif dan berhasil memecahkan berbagai masalah yang bersifat kompleks, (c) keterampilan siswa untuk mencari dan mendapatkan informasi akan meningkat, (d) mengembangkan dan mempraktikan keterampilan komunikasi dan kerjasama [1].

Kemampuan pemecahan masalah merupakan tingkat tertinggi dari proses belajar dan terdapat usaha untuk menemukan jawaban atau penyelesaian atas suatu persoalan dengan terlebih dahulu mengetahui gambaran dan karakteristik masalah yang dihadapi. Kemampuan pemecahan masalah diartikan sebagai kemampuan seseorang untuk menemukan solusi melalui suatu proses yang melibatkan pemerolehan dan pengorganisasian informasi [15].

Menurut Greenstein, langkah-langkah yang dilakukan dalam pemecahan masalah adalah 1) memahami permasalahan; 2) mengemukakan semua kemungkinan solusi pemecahan masalah; 3) menyusun rencana pemecahan masalah; 4) melaksanakan rencana pemecahan masalah; 5) mengevaluasi hasil [7]. Sejalan dengan langkah-langkah tersebut, Sanjaya juga secara ringkas mengemukakan lima langkah penyelesaian masalah melalui kegiatan kelompok, yaitu mendefinisikan masalah, mendiagnosis masalah, merumuskan alternatif strategi, menentukan dan menerapkan strategi pilihan, dan melakukan evaluasi keberhasilan strategi [14].

Materi Bioteknologi merupakan materi yang diajarkan di kelas IX SMP pada semester ganjil. Standar kompetensi dari materi pokok ini yaitu SK 2. Memahami kelangsungan hidup makhluk hidup. Adapun kompetensi dasar dari materi ini yaitu KD 2.4. Mendeskripsikan penerapan bioteknologi dalam mendukung kelangsungan hidup manusia melalui produksi pangan. Hal ini berarti bahwa peserta didik tidak hanya dituntut untuk memahami teori mengenai bioteknologi saja, melainkan juga dituntut untuk terlibat dalam pengaplikasian langsung dalam kehidupan nyata melalui penerapan bioteknologi untuk menghasilkan suatu produk pangan.

Tabel 1. Sintaks Model Pembelajaran Berbasis Proyek

\begin{tabular}{|c|c|c|}
\hline Fase & Aktivitas Siswa & Aktivitas Guru \\
\hline $\begin{array}{l}\text { Goal description } \\
\text { (Deskripsi tujuan) }\end{array}$ & Tahap 1: mendeskripsikan materi & $\begin{array}{l}\text { Menjelaskan masalah, } \\
\text { mengoordinasikan siswa, } \\
\text { dan memberikan motivasi }\end{array}$ \\
\hline $\begin{array}{l}\text { Sprcify criteria } \\
\text { (Menetapkan kriteria) }\end{array}$ & Tahap 2: mendefenisikan masalah & $\begin{array}{l}\text { Mengarahkan siswa pada } \\
\text { penyelidikan }\end{array}$ \\
\hline $\begin{array}{l}\text { Background } \\
\text { knowledge } \\
\text { (Pengetahuan dasar) }\end{array}$ & Tahap 3: meneliti masalah & $\begin{array}{l}\text { Membimbing dan } \\
\text { mengarahkan siswa untuk } \\
\text { menemukan informasi } \\
\text { tentang masalah dari hasil } \\
\text { investigasi atau } \\
\text { penyelidikan }\end{array}$ \\
\hline
\end{tabular}

\begin{tabular}{ll}
\hline $\begin{array}{l}\text { Generated ideas } \\
\text { (Membangun ide) }\end{array}$ & Tahap 4: mengetahui stakeholder; \\
\hline
\end{tabular}

Implement solution (Mengimplementasik an solusi) Reflect Tahap 6: mengembangkan rencana Menilai, berkolaborasi, (Refleksi)

\begin{tabular}{lll}
\hline $\begin{array}{l}\text { Generalize } \\
\text { (Mengeneralisasi) }\end{array}$ & $\begin{array}{l}\text { Tahap 7: mengimplementasikan } \\
\text { rancangan; Tahap 8: Merangkum, } \\
\text { mengevaluasi dan Merefleksikan }\end{array}$ & $\begin{array}{l}\text { Mengorganisir jalannya } \\
\text { presentasi, memberikan } \\
\text { refleksi dan penilaian. }\end{array}$ \\
\hline
\end{tabular}

Sumber: Ref. [10]. 


\section{METODE PENELITIAN}

Penelitian ini merupakan jenis penelitian pre-experimental dengan menggunakan rancangan berupa OneGroup Pretest-Posttest Design. Variabel penelitian terdiri dari dua, 1) Variabel bebas yaitu penerapan model pembelajaran berbasis proyek, 2) Variabel terikat yaitu kemampuan pemecahan masalah peserta didik. Kemampuan pemecahan masalah merupakan indikator dari efektivitas penerapan model pembelajaran berbasis proyek, dikatakan efektif jika: a) $\geq 75 \%$ dari peserta didik memiliki $N$-gain pada kategori sedang dan/atau tinggi; b) Secara statistika, kemampuan pemecahan masalah peserta didik menunjukkan perbedaan yang signifikan antara sebelum dan setelah pembelajaran.

Populasi dalam penelitian ini adalah seluruh rombongan belajar siswa kelas IX SMP Negeri 1 Maiwa tahun ajaran 2015/2016 yakni kelas IX IX $_{2}$, IX $_{3}$, IX $_{4}$, $\mathrm{IX}_{5}$, dan $\mathrm{IX}_{6}$. Adapun sampel dalam penelitian ini adalah rombongan belajar siswa kelas $\mathrm{IX}_{2}$ yang terdiri dari 22 orang dan $\mathrm{IX}_{3}$ yang terdiri dari 18 orang yang diambil dengan teknik random sampling. Penelitian ini berlangsung pada semester ganjil tahun ajaran 2015/2016 dan dilaksanakan di SMP Negeri 1 Maiwa yang berlokasi di Jalan Jendral Sudirman No. 47 Maroangin, Kelurahan Bangkala, Kecamatan Maiwa, Kabupaten Enrekang, Provinsi Sulawesi Selatan, Indonesia

Penelitian ini dilaksanakan dengan dua tahap yaitu tahap persiapan dan tahap pelaksanaan. Kegiatan yang dilakukan pada tahap persiapan diantaranya: 1) melakukan observasi untuk mendapatkan informasi yang dibutuhkan dalam pembuatan rencana penelitian dan meminta izin kepada pihak sekolah untuk mendapatkan izin penelitian; 2) pembuatan rancangan penelitian; 3) melakukan validasi instrumen penelitian yaitu soal untuk pretest dan posttest; 4) melakukan validasi instrumen yang mendukung dalam kegiatan pembelajaran pada saat penelitian yaitu silabus, rencana pelaksanaan pembelajaran, lembar kerja peserta didik; 5) mengurus surat izin dari fakultas; 6) mempersiapkan diri dengan melakukan pendalaman materi pada materi bioteknologi; 7) melakukan kegiatan adaptasi dengan cara ikut serta dalam kegiatan belajar mengajar IPA.

Adapun kegiatan yang dilakukan pada tahap pelaksanaan adalah 1) pemberian pretest yang dilanjutkan dengan pengenalan materi dasar bioteknologi, pembentukan kelompok proyek, pemberian pertanyaan mendasar yang mengantarkan pada ide awal proyek, melakukan kajian literatur, menuliskan dan mendiskusikan rancangan proyek yang akan dilakukan; 2) presentasi rancangan proyek yang disepakati, memulai pelaksanaaan proyek yang telah direncanakan, setelah itu melakukan peninjauan ulang terhadap hasil proyek sebelum presentasi akhir; 3) presentasi hasil akhir proyek, melakukan evaluasi dan refleksi, serta pemberian posttest.

Instrumen penelitian yang digunakan dalam penelitian ini adalah tes kemampuan pemecahan masalah yang dikembangkan oleh Assayidiyah yang kemudian disesuaikan dengan mata pelajaran dalam penelitian ini yaitu IPA pada materi bioteknologi [3]. Tes ini berbentuk soal esai (uraian) berjumlah 7 butir soal yang dilengkapi dengan rubrik penilaian kemampuan pemecahan masalah dan telah divalidasi oleh validator ahli Center of Inovation and Development of Biology Department (CID). Adapun, nilai tiap soal yang diperoleh siswa akan dianalisis dengan menggunakan rumus :

Nilai $=\frac{\text { Skor peroleha siswa }}{\text { skor maksimum tiap butir soal }} x$ bobot soal

Hasil yang diperoleh menjadi dasar untuk menentukan kategori kemampuan pemecahan masalah peserta didik. Hasil 
Nurul Arifah Sofyan, Hamka L, dan Andi Rahmat Saleh
Keefektifan Penerapan Model Pembelajaran Berbasis Proyek Terhadap Kemampuan Pemecahan Masalah Peserta Didik pada Materi Bioteknologi persentase akhir ditafsirkan menggunakan kriteria penafsiran, sebagaimana yang terdapat dalam Tabel 2.

Tabel 2. Kriteria Penafsiran Kemampuan Pemecahan Masalah Peserta Didik

\begin{tabular}{ccc}
\hline No. & $\begin{array}{c}\text { Persentase } \\
(\boldsymbol{\%})\end{array}$ & Kategori \\
\hline 1. & $81-100$ & Sangat Tinggi \\
\hline 2. & $61-80$ & Tinggi \\
\hline 3. & $41-60$ & Sedang \\
\hline 4. & $21-40$ & Rendah \\
\hline 5. & $<21$ & Sangat Rendah \\
\hline
\end{tabular}

Sumber: Ref. [13].

Data yang diperoleh dari hasil penelitian kemudian dianalisis dengan menggunakan teknik analisis statistik deskriptif, $\mathrm{N}$-gain dan analisis statistik inferensial. Analisis statistik deskriptif dimaksudkan untuk mendeskripsikan karakteristik distribusi skor kemampuan pemecahan masalah peserta didik dalam analisis persentase menggunakan tabel distribusi, baik sebelum maupun setelah pembelajaran IPA materi bioteknologi menggunakan model pembelajaran berbasis proyek. Hasil analisis deskriptif ditampilkan dalam bentuk skor rata-rata, skor maksimum, skor minimum, presentase dan distribusi frekuensi. Peningkatan yang terjadi sebelum dan sesudah pembelajaran dihitung dengan rumus gain ternormalisasi ( $N$-gain $)$ sebagai berikut

$$
g=\frac{S_{\text {post }}-S_{\text {pre }}}{S_{\text {maks }}-S_{\text {pre }}}
$$

dengan :

$\mathrm{S}_{\text {post }}=$ Skor tes akhir

$S_{\text {pre }}=$ Skor tes awal

$\mathrm{S}_{\text {maks }}=$ Skor maksimum yang mungkin dicapai

Adapun Kriteria tingkat $N$-gain dapat dilihat pada Tabel 3. sebagai berikut:

Tabel 3. Kategori Tingkat N-gain

\begin{tabular}{cc}
\hline Batasan & Kategori \\
\hline $\mathrm{g}>0,7$ & Tinggi \\
\hline $0,3 \leq \mathrm{g} \leq 0,7$ & Sedang \\
\hline $\mathrm{g}<0,3$ & Rendah \\
\hline
\end{tabular}

Sumber: Ref. [13].
Analisis statistik inferensial digunakan untuk menguji hipotesis penelitian. Uji $\mathrm{t}$ yang digunakan yaitu paired sample T-test. Pengujian hipotesis menggunakan program SPSS versi 18. Sebelum uji hipotesis dilakukan maka terlebih dahulu dilakukan uji normalitas (One Sample KolmogorovSmirnov Test) menggunakan bantuan aplikasi SPSS versi18dengan taraf $\alpha=0,05$. Sampel terdistribusi normal jika nilai sig. (2-tailed) $>\alpha$ dan sebaliknya jika nilai sig. (2-tailed) $\leq \alpha$, maka sampel tidak terdistribusi normal.

\section{HASILPENELITIAN}

Hasil analisis deskriptif bertujuan untuk mendeskripsikan kemampuan pemecahan masalah peserta didik kelas $\mathrm{IX}_{2}$ dan $\mathrm{IX}_{3}$ SMP Negeri 1 Maiwa yang dibelajarkan dengan menggunakan model pembelajaran berbasis proyek pada materi bioteknologi. Distribusi nilai pretest dan posttest peserta didik yang dibelajarkan menggunakan model pembelajaran berbasis proyek dapat dilihat pada Tabel 4.

Tabel 4. Distribusi Nilai Pretest dan Posttest

\begin{tabular}{cccc}
\hline \multirow{2}{*}{ No. } & Statistik & \multicolumn{2}{c}{ Nilai } \\
\cline { 3 - 4 } & & Pretest & Posttest \\
\hline 1. & $\begin{array}{c}\text { Jumlah } \\
\text { sampel }\end{array}$ & 40 & 40 \\
\hline 2. & Rata-rata & 29.46 & 69.25 \\
\hline 3. & $\begin{array}{c}\text { Nilai } \\
\text { terendah }\end{array}$ & 3 & 20 \\
\hline 4. & $\begin{array}{c}\text { Nilai } \\
\text { tertinggi }\end{array}$ & 69 & 89 \\
\hline
\end{tabular}

Distribusi nilai pretest dan posstest peserta didik pada Tabel 4. menunjukkan bahwa nilai rata-rata pretest adalah 29.46 dan nilai rata-rata posttest adalah 69.25. Hal ini menunjukkan bahwa telah terjadi peningkatan kemampuan pemecahan masalah peserta didik setelah diajar menggunakan model pembelajaran berbasis proyek yaitu sebesar 39.79 .

Data nilai pretest dan posstest peserta didik yang diperoleh kemudian dikelompokkan kedalam tabel pengkategorian yang mengacu pada kriteria penafsiran kemampuan pemecahan masalah yang telah ditentukan. Distribusi frekuensi dan persentase kategori nilai pretest dan posttest peserta didik yang dibelajarkan 
dengan model pembelajaran berbasis proyek dapat dilihat pada Tabel 5.

Tabel 5. Distribusi Frekuensi dan Persentase Kategori Nilai Pretest dan Posttest Peserta Didik yang Dibelajarkan dengan Model Pembelajaran Berbasis Proyek

\begin{tabular}{|c|c|c|c|c|}
\hline \multirow{2}{*}{ No. } & \multicolumn{2}{|c|}{ Pretest } & \multicolumn{2}{|c|}{ Posttest } \\
\hline & Frekuensi & Persentase (\%) & Frekuensi & $\begin{array}{c}\text { Persentase } \\
(\%)\end{array}$ \\
\hline 1. & Sangat Tinggi & 0 & 10 & 25 \\
\hline 2. & Tinggi & 2.5 & 20 & 50 \\
\hline 3. & Sedang & 22.5 & 8 & 20 \\
\hline 4. & Rendah & 47.5 & 1 & 2.5 \\
\hline 5. & Sangat Rendah & 27.5 & 1 & 2.5 \\
\hline Jumlah & 40 & 100 & 40 & 100 \\
\hline \multicolumn{2}{|c|}{$\begin{array}{l}\text { Distribusi frekuensi dan persentase } \\
\text { tegori nilai pretest dan posttest peserta } \\
\text { dik pada Tabel 5. menunjukkan bahwa } \\
\text { lah terjadi peningkatan kemampuan } \\
\text { emecahan masalah peserta didik setelah } \\
\text { belajarkan dengan menggunakan model } \\
\text { embelajaran berbasis proyek. } \\
\text { ada penelitian ini juga digunakan analisis } N \text { - } \\
\text { iin. Analisis ini digunakan untuk } \\
\text { engetahui keefektifan penerapan model } \\
\text { embelajaran berbasis proyek terhadap ke- } \\
\text { ampuan pemecahan masalah peserta didik } \\
\text { engan melihat seberapa besar peningkatan } \\
\text { emampuan pemecahan masalah peserta } \\
\text { dik sebelum dan setelah pembelajaran } \\
\text { lakukan. Berikut disajikan hasil analisis } N \text { - } \\
\text { ain kemampuan pemecahan peserta didik } \\
\text { ang dapat dilihat pada Tabel } 6 \text {. } \\
\text { abel 6. Frekuensi dan Kategori N-gain } \\
\text { emampuan PemecahanMasalah Peserta } \\
\text { idik }\end{array}$} & \multirow{6}{*}{\multicolumn{3}{|c|}{ 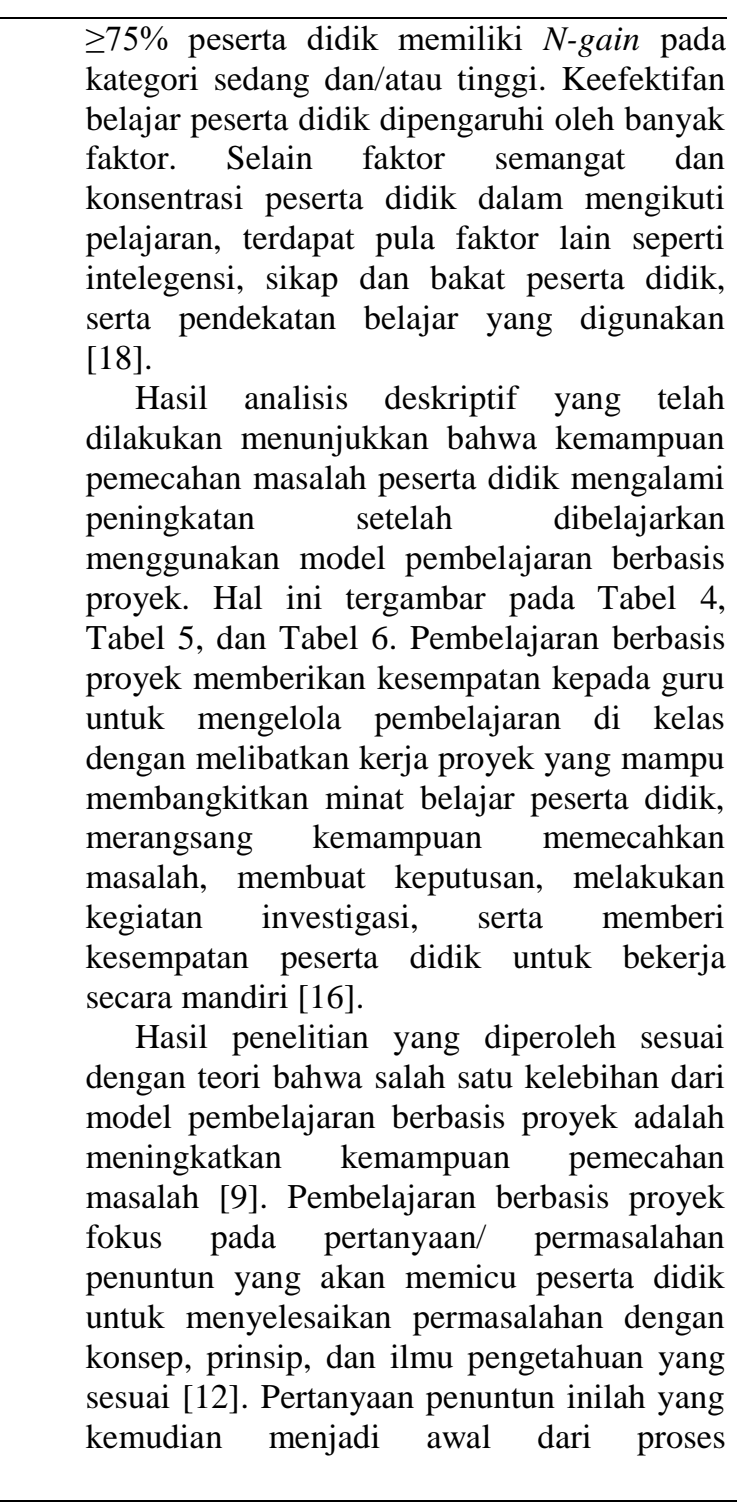 }} \\
\hline Kate & $\begin{array}{llc}\text { gori } & \text { Frekuensi } & \begin{array}{c}\text { Persentase } \\
(\%)\end{array} \\
\end{array}$ & & & \\
\hline Tin & 22.5 & & & \\
\hline Sed & 28 & & & \\
\hline Ren & 7.5 & & & \\
\hline $\begin{array}{l}\text { Fre } \\
\text { kemam } \\
\text { didik } \\
\text { sebany } \\
\text { memili } \\
\text { dan/ata } \\
\text { penera } \\
\text { proyek } \\
\text { pemeca }\end{array}$ & $\begin{array}{l}\text { uensi dan kategori } N \text {-gain } \\
\text { ouan pemecahan masalah peserta } \\
\text { ada Tabel 6. menunjukkan bahwa } \\
\text { k } 37 \text { orang }(92.5 \%) \text { dari peserta didik } \\
\text { i } N \text {-gain pada kategori sedang } \\
\text { tinggi. Data ini menunjukkan bahwa } \\
\text { an model pembelajaran berbasis } \\
\text { efektif terhadap kemampuan } \\
\text { aan masalah peserta didik karena }\end{array}$ & & & \\
\hline
\end{tabular}


penemuan (inqury) dan membimbing peserta didik dalam sebuah proyek kolaboratif.

Analisis statistik inferensial dilakukan untuk menjawab hipotesis penelitian yang telah dirumuskan. Hasil analisis inferensial yang telah dilakukan juga menunjukkan nilai signifikansi yang diperoleh melalui uji paired sample T-testdengan menggunakan program SPSS versi 18 yaitu sig. (2-tailed) $0,000<\alpha$ $=0,05$. Hal ini membuktikan bahwa $\mathrm{H}_{0}$ ditolak dan $\mathrm{H}_{1}$ diterima yang berarti bahwa penerapan model pembelajaran berbasis proyek efektif terhadap kemampuan pemecahan masalah peserta didik kelas IX SMP Negeri 1 Maiwa pada materi Bioteknologi. Hasil ini sejalan dengan hasil penelitian yang dilakukan Arimbawa, mengemukakan bahwa model pembelajaran berbasis proyek memiliki keunggulan komparatif dibandingkan dengan model pembelajaran konvensional dalam hal meningkatkan kemampuan pemecahan masalah IPA peserta didik [2]. Hasil penelitian dari Karina juga mengungkapkan bahwa terdapat perbedaan kemampuan pemecahan masalah fisika dan kecerdasan emosional antara siswa yang dibelajarkan dengan model pembelajaran berbasis proyek dengan siswa yang dibelajarkan dengan model pembelajaran konvensional [8].

Model pembelajaran berbasis proyek pada penelitian ini terdiri dari tujuh fase dan kemampuan pemecahan masalah peserta didik meliputi lima aspek yaitu mengidentifikasi masalah, mendiagnosis masalah, merumuskan alternatif strategi, menentukan dan menerapkan strategi pilihan, dan melakukan evaluasi. Kegiatan yang dilakukan guru pada fase pertama adalah menyampaikan tujuan pembelajaran, memberikan penjelasan singkat terkait materi bioteknologi dan mengarahkan peserta didik pada masalah mengenai potensi sumber daya alam yang melimpah namun kurang dimanfaatkan secara optimal melalui media powerpoint.

Kegiatan pada fase pertama akan memberikan gambaran awal kepada peserta didik tentang pembelajaran pada saat itu, dan mengembangkan kemampuan pemecahan masalah peserta didik pada aspek mengidentifikasi masalah. Pengidentifikasian masalah sangat penting karena akan berhubungan dengan kejelasan dan kesamaan persepsi tentang masalah serta berkaitan dengan data-data apa yang harus dikumpulkan untuk penyelesaiannya [14].

Fase kedua adalah mengarahkan peserta didik pada penyelidikan. Peserta didik dibimbing untuk menentukan ide awal proyek dengan tema "Bioteknologi di Sekitar Kita". Kegiatan ini dilakukan dalam kelompok dan setiap kelompok didampingi oleh seorang pendamping. Peserta didik diberikan lembar rancangan proyek yang berisi pertanyaan mendasar yaitu "Apa sajakah potensi Sumber Daya Alam yang ada di sekitar Anda?", "Dapatkah potensi SDA tersebut diolah menjadi produk bioteknologi konvensional?", dan "Bagaimana Anda me-manfaatkannya menjadi produk bioteknologi konvensional?”.

Pertanyaan mendasar pada lembar rancangan proyek akan mengantarkan peserta didik pada ide awal proyek yang akan dilakukan. Pada tahap ini, peserta didik telah menentukan sumber daya alam berupa sayursayuran, kacang-kacangan, dan susu yang akan dikembangkan menjadi produk bioteknologi. Fase ini dapat mengakomodasi untuk melatih kemampuan pemecahan masalah peserta didik pada aspek mengidentifikasi masalah, mendiagnosis masalah, merumuskan alternatif strategi.

Fase ketiga dan keempat berupa bimbingan, diskusi kelompok dan kajian literatur untuk menemukan informasi tentang produk apa yang dapat dihasilkan dari sumber daya alam yang telah dipilih oleh masing-masing kelompok. Peserta didik tetap berpedoman pada lembar rancangan proyek yang telah diberikan dan tetap didampingi oleh seorang pendamping kelompok. Tahap ini dapat melatih kemampuan pemecahan masalah peserta didik pada aspek mengidentifikasi masalah, mendiagnosis masalah, merumuskan alternatif strategi, menentukan dan menerapkan strategi pilihan.

Fase selanjutnya yang mengakomodasi berkembangnya kemampuan pemecahan masalah peserta didik adalah fase kelima dan keenam. Kegiatan yang dilakukan pada fase ini berupa presentasi rancangan proyek yang telah dibuat oleh setiap kelompok yang disertai proses tanya jawab. Diskusi mendorong peserta didik untuk berpikir mengemukakan pendapat dan argumentasi tentang kemungkinan setiap tindakan yang dapat dilakukan [14]. Guru bertindak sebagai moderator dan memberikan saran agar 
kekurangan pada setiap kelompok dapat diperbaiki sehingga dihasilkan rencana proyek yang jelas pada setiap kelompok.

Pengerjaan rancangan proyek yang termasuk fase ketujuh juga memiliki potensi untuk mengembangkan kemampuan pemecahan masalah pada aspek menentukan dan menerapkan strategi pilihan, dan melakukan evaluasi. Peserta didik mengerjakan proyek pembuatan produk bioteknologi yang direncanakan sebelumnya. Pada proses pelaksanaan proyek, peserta didik berpedoman pada lembar perencanaan proyek yang telah dibuat. Lembar ini dilengkapi dengan lembar penyusunan jadwal dan pembagian tugas dalam kelompok sehingga peserta didik dapat menyelesaikan proyek sesuai jadwal yang telah ditetapkan. Adanya proses pembuatan atau pelaksanaan proyek yang bersifat autentik, konstruktif dalam pembelajaran menyebabkan peserta didik mempelajari keterampilan dasar yang baru dan mengalami peningkatan pengetahuan [12].

Produk bioteknologi yang dihasilkan peserta didik melalui model pembelajaran berbasis proyek adalah tempe dari kacang tanah, yoghurt, dan kimchi. Produk yang dihasilkan kemudian diuji melalui uji organoleptik dengan berdasarkan pada indikator: tekstur, rasa, aroma, dan warna. Hasil produk bioteknologi peserta didik disajikan pada Gambar 1, Gambar 2, dan Gambar 3.

Semua bahan seperti kacang tanah, susu kerbau, dan sayur-sayuran yang digunakan untuk membuat produk bioteknologi berasal dari sumber daya alam yang ada disekitar lingkungan peserta didik. Setelah 2 hari dari proses pembuatan produk, tempe kacang tanah yang dihasilkan memiliki tekstur yang padat dengan hifa yang berwarna putih yang tersebar merata pada permukaan tempe. Yoghurt yang dihasilkan bertekstur sedikit kental dengan aroma dan rasa yang asam. Peserta didik kemudian berinisiatif untuk menambahkan cita rasa dan warna dari yoghurt agar terlihat lebih menarik dengan menambahkan sari buah naga. Adapun kimchi yang dihasilkan memiliki rasa asam, manis, dan asin dengan aroma bawang yang khas.

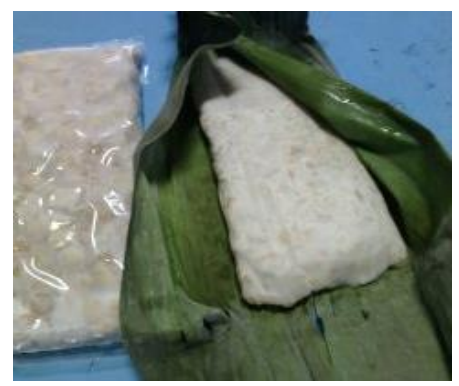

Gambar 1. Tempe Kacang Tanah

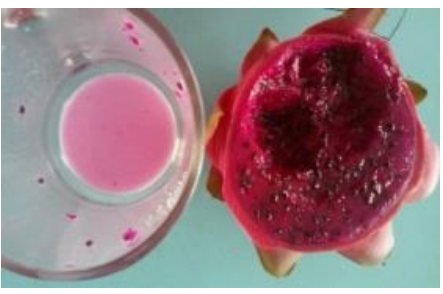

Gambar 2. Yoghurt dengan tambahan sari buah naga

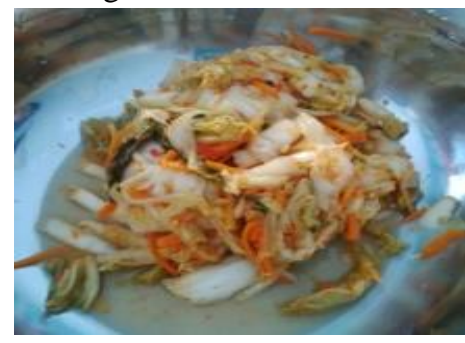

Gambar 3. Kimchi

Pada akhir pertemuan dilakukan presentasi hasil pengerjaan proyek. Setiap kelompok mempresentasikan rincian pelaksanaan proyek melalui poster yang telah dibuat. Adapun poster yang dihasilkan disajikan pada Gambar 4. Guru bertindak sebagai moderator, memberikan saran dan perbaikan serta menentukan kelompok terbaik yang didasarkan pada kerjasama kelom-pok, presentasi proyek, dan nilai poster yang diperoleh. Penilaian poster juga mengacu pada kriteria: judul, kejelasan gambar yang ditampil-kan, keterkaitan gambar, keterangan gambar/pelabelan, isi, dan kemenarikan poster.

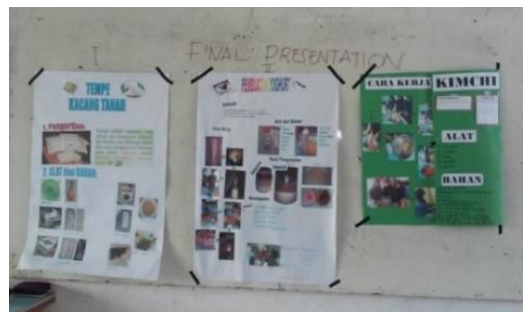

Gambar 4. Poster setiap kelompok proyek 
Nurul Arifah Sofyan, Hamka L, dan Andi Rahmat Saleh
Keefektifan Penerapan Model Pembelajaran Berbasis Proyek Terhadap Kemampuan Pemecahan Masalah Peserta Didik pada Materi Bioteknologi
Hasil analisis yang telah dilakukan menunjukkan bahwa $92.5 \%$ peserta didik memiliki $N$-gain pada kategori sedang dan/atau tinggi dan secara statistik nilai pretest dan posttest berbeda secara signifikan. Hal ini berarti penerapan model pembelajaran berbasis proyek efektif terhadap kemampuan pemecahan masalah peserta didik kelas IX pada materi Bioteknologi.

Keefektifan penerapan model pembelajaran berbasis proyek tidak terlepas dari beberapa faktor yang diterapkan selama proses pembelajaran. Faktor tersebut diantaranya adalah adanya team teaching yang dibentuk selama proses pembelajaran, penggunaan media powerpoint untuk mendukung jalannya pre-sentasi pada saat penyampaian materi dan ide awal proyek, dan adanya lembar perencanaan proyek yang dilengkapi dengan lembar penyusunan jadwal dan pembagian tugas dalam kelompok untuk setiap peserta didik sehingga dapat fokus terhadap pertanyaan/permasalahan yang akan dipecahkan.

\section{KESIMPULAN}

Berdasarkan hasil analisis dan pembahasan yang telah dilakukan maka dapat disimpulkan bahwa penerapan model pembelajaran berbasis proyek efektif terhadap kemampuan pemecahan masalah peserta didik kelas IX SMP Negeri 1 Maiwa pada materi Bioteknologi.

\section{DAFTAR PUSTAKA}

[1] Al-Ansori, A. 2012. Penerapan Model PjBL (Project Based Learning) dalam Upaya Meningkatkan Kreatifitas Siswa pada Konsep Pencemaran Lingkungan di MAN Babakan Ciwaringin Cirebon. Skripsi. Cirebon: Institut Agama Islam Negeri (IAIN) Syekh Nurjati.

[2] Arimbawa, P., Wayan S., \&Nyoman T. 2013. Pengaruh Model Pembelajaran Berbasis Proyek (MPBP) terhadap Kemampuan Pemecahan Masalah IPA Sehari-hari Ditinjau dari Motivasi Berprestasi Siswa. e-Journal Program Pascasarjana Uni-versitas Pendidikan Ganesha Program Studi IPA (Online), Vol. 3. Tahun 2013 (http://pasca.undiksha.ac.id/e- journal/index.php/jurnal_ipa/article/ viewFile/852/607, diakses 8 Februari 2015).

[3] Assayidiyah, B. F. 2014. Pengaruh Aktivias Belajar Siswa dalam Pembelajaran Problem Based Learning Terhadap Ke-mampuan Pemecahan Masalah pada Materi Pencemaran Lingkungan di SMAN 1 Kandanghaur Indramayu. Skripsi. Indramayu: Program Studi Pendidikan Biologi Fakultas Keguruan dan Ilmu Pendidikan Universitas Wiralodra.

[4] Badan Standar Nasional Pendidikan. 2010. Laporan BSNP Tahun 2010. Jakarta: Badan Standar Nasional Pendidikan.

[5] Bahri, A. 2009. Sistem Pembelajaran Abad 21 dengan Project Based Learning (PBL)

(Online).http://www.ubb.ac.id/menule ngkap.php?judul $=$ Sistem $\%$

20Pembelajaran $\% 20$ Abad $\% 2021 \% 20$ dengan $\% 20 \% 3 \mathrm{CQ} \% 3 \mathrm{EProject} \% 20 \mathrm{Bas}$ ed\%20Learning\%20\%28PBL\%29\%3 C/Q\%3E\&\&nomorurut artikel=252, diakses 8 Februari 2015.

[6] Bellanca, J. 2012. Proyek Pembelajaran yang Diperkaya: Jalur Praktis Menuju Keterampilan Abad ke-21. Jakarta: Indeks.

[7] Greenstein, L. 2012. Assessing 21 ${ }^{\text {st }}$ Century Skill: A Guide to Evaluating Mastery and Authentic Learning. United States of America: Corwin A Sage Company.

[8] Karina, N. K. D., I. W. Sadia., \& I. W. Suastra. 2014. Pengaruh Model Pembelajaran Berbasis Proyek Terhadap Kemampuan Pemecahan Masalah dan Kecerdasan Emosional Siswa SMP. E-Journal Program Pasca Sarjana Univer-sitas Pendidikan Ganesha. Vol 4. Tahun 2014.

[9] Kementerian Pendidikan dan Kebudayaan. 2013. Materi Pelatihan Guru Imple-mentasi Kurikulum 2013 SMP/MTs Ilmu Pengetahuan Alam. 
Nurul Arifah Sofyan, Hamka L, dan Andi Rahmat Saleh

Jakarta: Badan Pengembangan Sumber Daya Manusia Pendidikan dan Kebudayaan dan Pen-jaminan Mutu Pendidikan Kementerian Pendidikan dan Kebudayaan.

[10] Mihardi S., Mara B.H., \& Ridwan A.S. 2013. The Effect of Project Based Learning Model with KWL Worksheet on Student Creative Thinking Process in Physics Problems. Journal of Education and Practice. Vol. 4, No. $25,2013$.

[11] Okudan, G. E. \& Sarah E.R. 2004. A Project-Based Approach to Entreprenurial Leadership Education. Journal Technovation. Desember. Volume XX. Page 1-16.

[12] Priansa, D. J.\&Ani S. 2015. Manajemen Peserta Didik dan Model Pembelajaran. Bandung: Alfabeta.

[13] Riduwan. 2014. Dasar-dasar Statistika. Bandung: Alfabeta.

[14] Sanjaya, W. 2013. Strategi Pembelajaran Berorientasi Standar ProsesPendidikan. Jakarta: Kencana

[15] Sujarwanto, E.,Hidayat, \&Wartono. 2014. Kemampuan Pemecahan Masalah Fisika pada Modeling Instruction pada Siswa SMA Kelas XI. Jurnal Pendidikan IPA Indonesia. April. Volume 3, Nomor 1, Halaman 65-78.

[16] Thomas, J. W. 2000. A Review of Research on Project Based Learning. California: The Autodesk Foundation.

[17] Trianto. 2009. Mendesain model pembelajaran inovatif-progresif. Penerbit: kencana prenada media group: Jakarta.

[18] Uno, H. B.\& Nurdin M. 2013. Belajar dengan pendekatan PAILKEM. Jakarta: PT.Bumi Aksara.

[19] Widyaiswara, R. 2014. Pembelajaran Berbasis Proyek (Project Based Learning) dalam Materi Statistika
Keefektifan Penerapan Model Pembelajaran Berbasis Proyek Terhadap Kemampuan Pemecahan Masalah Peserta Didik pada Materi Bioteknologi
SMP (Online). E-Buletin LPMP Sulawesi Selatan Edisi Desember 2014, http://www.lpmpsulsel.net, diakses 16 Februari 2015. 